\title{
Pengembangan desain E-Bike ITSB model 2.0. untuk kendaraan patroli keamanan kawasan terpadu
}

\author{
Wildan Aulia,$^{1 *}$ Heru Widodo ${ }^{2}$ \\ ${ }^{1}$ Program Studi Desain Produk, Institut Teknologi Sains Bandung, Bekasi, Indonesia \\ ${ }^{2}$ Program Studi Perencanaan Wilayah Kota, Institut Teknologi Sains Bandung, Bekasi, Indonesia
}

\begin{abstract}
E-Bike ITSB is a solar powered electric commuter vehicle developed by ITSB since 2016. The first E-Bike ITSB model has entered the production simulation stage which began in 2017. According to the ITSB Product Design Study Center roadmap, E-Bike ITSB must begin to enter the utility expansion stage. One of the potential needs to be met by the E-Bike ITSB is an operational vehicle for security officers in an integrated area. Design aspects that are considered are the usability \& visual quality of the product, and user ergonomics/anthropometry. The design method was carried out through analitycal prototyping. Mobility studies are carried out by survey, interview and route mapping. The case study was conducted in Kota Deltamas. The design direction is obtained through perceptual mapping analysis which is used to identify the expected image on the product. The study results show that the second E-Bike ITSB model image is expected to lead to offroad-likemotorcycle-like. The specifications of the second E-Bike model cannot be the same as the first model. The e-bike must be able to go up to $80 \mathrm{~km} / \mathrm{hr}$. These requirements change the E-Bike ITSB in body frame, electrical and motor specifications.
\end{abstract}

Key words: E-Bike ITSB, electric vehicle, areas, patrols

\begin{abstract}
Abstrak
E-Bike ITSB merupakan kendaraan listrik bertenaga surya yang dikembangkan ITSB sejak tahun 2016 sebagai kendaraan commuter bagi mahasiswa ITSB. E-Bike ITSB model pertama telah masuk dalam tahap simulasi produksi yang dimulai sejak tahun 2017. Mengacu pada roadmap Pusat Studi Desain Produk ITSB, E-Bike ITSB harus mulai masuk ke dalam tahap perluasan fungsi. Salah satu kebutuhan yang berpotensi untuk dipenuhi oleh E-Bike ITSB adalah kendaraan operasional petugas keamanan kawasan terpadu. Aspek desain yang menjadi perhatian adalah aspek kegunaan, bentuk dan kualitas visual produk, serta ergonomi/antropometri pengguna. Metode perancangan desain dilakukan melalui studi bentuk dengan metode analitycal prototyping. Studi mobilitas kendaraan dilakukan dengan survei lapangan, wawancara dan pemetaan rute patroli. Studi kasus dilakukan di Kota Deltamas. Arah desain ditentukan melalui analisis perceptual mapping yang digunakan untuk mengidentifikasi image yang diharapkan pada produk. Hasil studi menunjukkan bahwa image E-Bike ITSB model kedua diharapkan mengarah ke offroad like - motorcycle like. Spesifikasi dan konfigurasi E-Bike model kedua tidak bisa sama dengan model pertama. Kapasitas motor harus lebih kuat dan dapat melaju hingga $80 \mathrm{~km} / \mathrm{jam}$. Hal ini mendorong perubahan model E-Bike pada bentuk rangka, spesifikasi kelistrikan dan motor.
\end{abstract}

Kata kunci: E-Bike ITSB, kendaraan listrik, kawasan, patroli

\section{Pendahuluan}

Kendaraan listrik saat ini menjadi isu global yang strategis. Potensi pengembangannya tidak terbatas pada konteks objek saja, namun juga pada perkembangan teknologi yang mengikutinya dan pengaruhnya pada aspek-aspek kehidupan. Hal ini menjadikan kendaraan listrik dapat diterapkan dalam konteks yang beragam. Pengembangan kendaraan listrik di Indonesia telah dilakukan melalui beberapa pendekatan, di antaranya melalui aspek sumber daya/batere, kekuatan rangka, ergonomi, aplikasi energi terbarukan, sistem mobilitas, dan desain produk industri. Jenis kendaraan listrik yang pernah dikembangkan di Indonesia cukup luas, mulai dari penerapan komponen kelistrikan pada sepeda yang telah ada, sepeda motor, mobil ringan, hingga mobil sport dan bus; hingga penelitian-penelitian

\footnotetext{
* Corresponding author Tel : +62-811-2190-282 ; e-mail : waidansmail@gmail.com
} 
pendukungnya meliputi uji rangka, batere, penerapan solar cell dan lain sebagainya. Perhatian publik terhadap pengembangan kendaraan listrik semakin tinggi, seperti mulai ramainya pameran otomotif berbasis listrik, perlombaan perancangan kendaraan listrik, hingga berdirinya perusahaan-perusahaan startup yang memfokuskan diri pada pengembangan energi listrik seperti Baran Energy yang dilaunching pada bulan Juli 2019 lalu. Bahkan di tahun 2019 ini, pengembangan kendaraan listrik menjadi isu strategis karena telah didukung oleh Peraturan Presiden yang sudah ditandatangani oleh Presiden Republik Indonesia pada Senin 6 Agustus 2019 serta akan diakomodasi oleh regulasi sehingga dapat menumbuhkan industri otomotif berbasis listrik.

Meskipun keberadaan kendaraan berbahan bakar fosil masih banyak dan terus diproduksi, namun keniscayaan penggunaan kendaraan listrik di Indonesia semakin besar. Beberapa jenis kendaraan listrik yang tidak berbenturan dengan regulasi telah menjadi alternatif alat transportasi yang marketable, seperti sepeda listrik. Jika regulasi dari pemerintah mengenai kendaraan bermotor berbasis listrik telah berjalan, maka perusahaan otomotif pun bisa mulai menjual motor dan mobil listrik kepada masyarakat. Infrastruktur yang berkaitan dengan hal tersebut tentu ikut menjadi hal yang harus dibangun dan dikembangkan. Penelitian-penelitian terdahulu mengenai infrastruktur pendukung mobilitas kendaraan listrik pun telah mulai dilakukan meskipun dalam skala yang kecil, seperti sistem transportasi kendaraan listrik pada kawasan-kawasan terpadu. Sistem ini menuntut perencanaan skema transportasi dan sarana pendukung yang didasarkan pada pola mobilitas populasi manusia di dalamnya (Aulia \& Widodo, 2018). Beberapa kawasan terpadu bahkan sudah mulai bekerjasama dengan perusahaan penyedia sarana commuter berbasis on line untuk penyediaan sistem transportasi publik berbasis listrik.

E-Bike ITSB yang dirancang oleh Giasa Lutfiah dan dikembangkan Program Studi Desain Produk ITSB merupakan kendaraan listrik commuter bertenaga surya yang dirancang khusus untuk diguna- kan di lingkungan kampus ITSB (Handoyo \& Lutfiah, 2016). Sambutan yang baik saat E-Bike ITSB pertama kali dipublikasikan pada tahun 2016 secara nasional mendorong Pusat Studi Desain Produk ITSB menetapkan roadmap pengembangan E-Bike ITSB, yaitu pada (1) sistem mobilitas dan sarana pendukung E-Bike ITSB, (2) perluasan fungsi penggunaan dan styling, (3) aplikasi teknologi sumber daya energi dan kelistrikan (Gambar 1).

Keputusan untuk mengembangkan E-Bike ITSB sebagai kendaraan operasional keamanan di kawasan Kota Deltamas adalah karena kebutuhan terhadap hal ini dapat teridentifikasi. Kota Deltamas merupakan kawasan terpadu milik Sinar Mas Land dengan luas 3200 hektare yang terbagi dalam tiga zona kawasan, yaitu zona industrial sebesar $54 \%$, zona komersial sebesar $24 \%$, dan zona residensial sebesar $22 \%$ (deltamas.id/masterplan). Setiap kawasan dihubungkan dengan jalan utama beraspal yang dapat dilalui kendaraan bermotor. Setiap kawasan memiliki sistem jalan tersendiri dengan jarak menengah. Dengan tipe kawasan dengan tipe kontur yang relatif datar, maka E-Bike ITSB dapat digunakan di kawasan Kota Deltamas. Berkaitan dengan kawasan Kota Deltamas yang akan dijadikan objek studi, maka penelitian sebelumnya mengenai aplikasi kendaraan listrik di kawasan Kota Deltamas telah pernah dilakukan, namun penelitian tersebut lebih memfokuskan pada alternatif kendaraan berbasis listrik model bis untuk sarana transportasi umum perumahan kawasan Kota Deltamas dengan skema feeder bus (Romli, 2018). Hal ini memberikan argumen bahwa penerapan kendaraan listrik di Kota Deltamas cukup potensial untuk dikembangkan.

Perancangan E-Bike ITSB menekankan pada aspek pengguna, sehingga perluasan penggunaan E-Bike ITSB sebagai kendaraan operasional keamanan tidak semata mempertimbangkan aspek teknis. Arah desain akan mengacu pada aspek fungsi dan pengguna. Selain itu, konfigurasi, spesifikasi dan dimensi produk akan disesuaikan dengan kebutuhan patroli keamanan di kawasan Kota Deltamas, di antaranya daya jelajah,

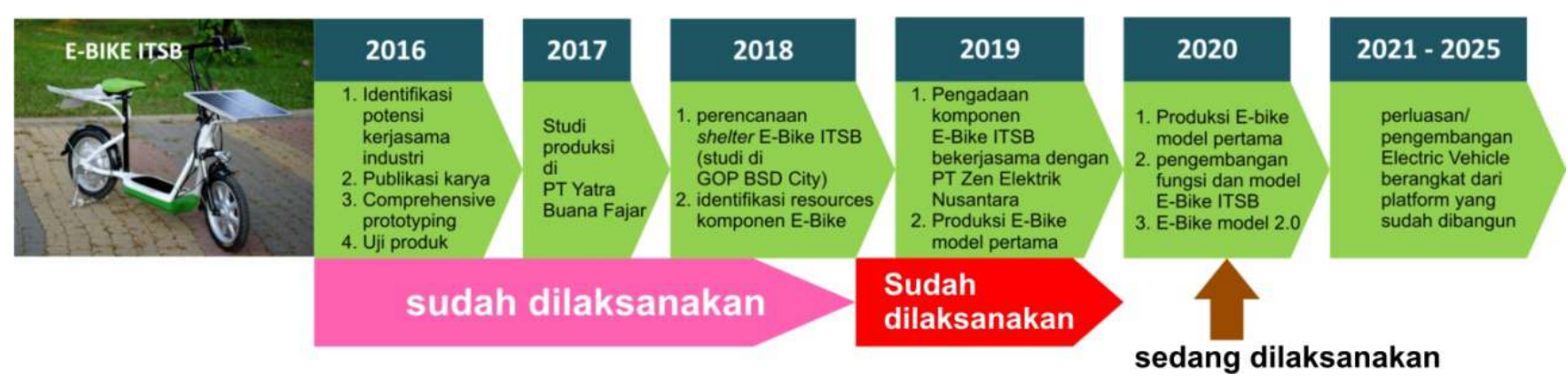

Gambar 1. Roadmap pengembangan E-Bike ITSB

(Sumber: resume dari roadmap Pusat Studi Desain Produk Industri ITSB) 
performa, ergonomi, serta physical impression E-Bike ITSB.

\section{Bahan dan metode}

Identifikasi kebutuhan kendaraan patroli keamanan dilakukan melalui wawancara dan survey lapangan. Data yang diperlukan dalam wawancara meliputi sistem patroli keamanan di Kota Deltamas termasuk pembagian area patroli, jarak, interval patroli, jumlah personil, pos, kendaraan yang digunakan dan rute patroli. Dokumentasi kawasan jalanan di Kota Deltamas dilakukan sebagai bagian dari studi lapangan untuk mengarahkan desain kendaraan patroli. Survey lapangan diteruskan dengan menandai titik pos istirahat patroli pada peta. Penandaan peta dibantu dengan pencitraan google map. Peta yang ditandai ditelusur oleh tim untuk dapat melihat kondisi rute patroli dalam keadaan sebenarnya. Hal ini penting dilakukan untuk dapat mengetahui kondisi medan/jalan yang sebenarnya serta untuk mengukur jarak antar pos yang menjadi data untuk mempertimbangkan jenis motor E-Bike. Meskipun rute dan lama berpatroli dapat berbeda-beda, namun skenario penggunaan motor secara umum dapat diidentifikasi berdasarkan jarak-jarak antar pos. Dengan demikian, maka perlu dilakukan sampling jarak terjauh dan terdekat.

Arah desain E-bike 2.0 ditetapkan melalui metode perceptual mapping. Pertimbangan menggunakan metode ini adalah karena user sangat spesifik. Penggunaan kendaraan operasional dibatasi pola tugas/patroli petugas keamanan. Image produk juga dapat dibatasi secara top down oleh perancang dengan menyetarakannya terhadap kendaraan-kendaraan patroli yang sudah ada. Dimensi relatif kendaraan dapat dibatasi karena ukuran antropometri petugas keamanan dapat dihingga dan dirata-rata karena tinggi badan dan postur petugas keamanan telah dipersyaratkan khusus dalam perekrutan. Perceptual mapping penting karena akan mengidentifikasi apa yang diharapkan terhadap image produk yang akan dirancang (Milton \& Rodgers, 2013). Peluang menemukan gap baru untuk menawarkan model EBike yang berbeda dengan kompetitor yang ada juga dapat diperoleh dari perceptual mapping. Perceptual mapping dilakukan dengan survey secara purposive sampling kepada pekerja dan mahasiswa yang aktifitas sehari-harinya berada di Kota Deltamas. Pemilihan responden dengan cara ini dilakukan karena mempertimbangkan faktor emosional responden terhadap fasilitas yang akan mereka lihat sehari-hari, sehingga harapan mereka terhadap image

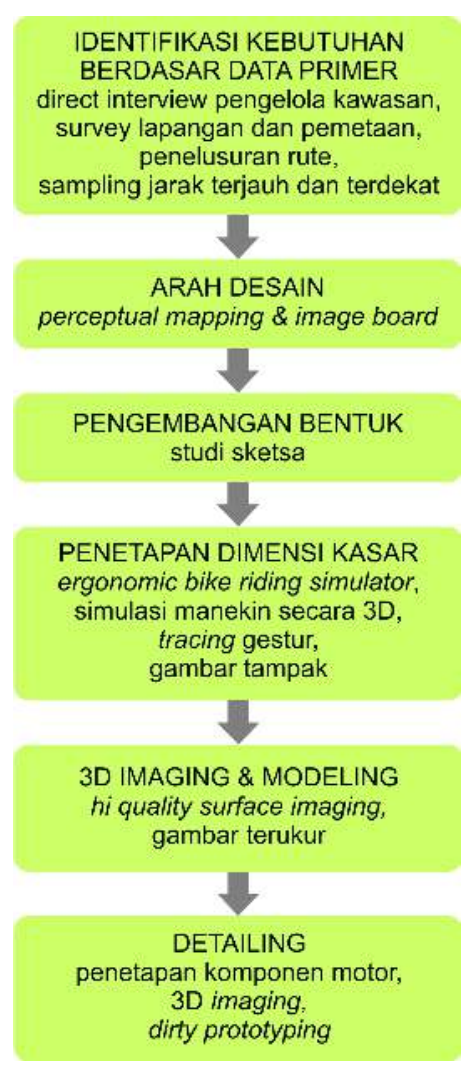

Gambar 2. Tahapan perancangan

produk yang akan dikembangkan dapat lebih muncul. Arah warna dan bidang dapat ditetapkan melalui image board.

Pencarian bentuk dilakukan melalui studi sketsa. Semua alternatif sudah diarahkan sesuai temuan pada perceptual mapping. Altenatif desain terpilih ditetapkan dengan mengasosiasikan dengan hasil perceptual mapping. Penetapan dimensi kasar produk diperoleh dengan metode analytical prototyping yang dibantu dengan program motorcycle ergonomic simulator. Hasil simulasi ditracing ke dalam program 3D untuk mendapatkan gestur pengendara yang sesuai dengan sketsa kasar. Penyesuaian ini menghasilkan garis vektor tampak samping E-Bike ITSB model 2.0. yang dapat diconvert dan dibangun di program 3D. Proses analytical prototyping diselesaikan di program 3D smax untuk mendapatkan bentuk dan ukuran utuh produk secara tiga dimensi. Tahapan perancangan secara diagramatik ditampilkan oleh Gambar 2.

\section{Hasil dan pembahasan}

Hasil wawancara menunjukkan bahwa kebutuhan berpatroli dalam konteks mobility di Kota Deltamas sebetulnya sudah terpenuhi dengan adanya lima mobil jenis minibus dan 11 motor trail. Tim patroli terbagi 
ke dalam empat tim dengan sistem patroli bergilir siaga 24 jam. Interval dan jarak patroli tidak ditentukan karena selalu bergantung pada kondisi lingkungan dan situasi lapangan. Namun bila dirataratakan, satu kali berpatroli memerlukkan waktu sekitar satu hingga dua jam. Sistem patroli bersifat semi terpusat, yaitu bertolak dari kantor Damkar MS Kota Deltamas yang didukung pos-pos tidak permanen yang disebar sesuai tingkat kerawanan lingkungan, bukan berdasarkan pembagian jarak. Pos lebih berfungsi untuk tempat istirahat personil patroli yang bertugas dan titik kumpul. Patroli dengan mobil dilakukan untuk radius/jarak di atas $20 \mathrm{~km}$. Sedangkan yang lebih pendek menggunakan sepeda motor. Kecepatan kendaraan dalam berpatroli dapat mencapai $70-80 \mathrm{~km} / \mathrm{jam}$. Patroli motor dibagi ke dalam empat zonasi, yaitu zona $\mathrm{A}$ dan $\mathrm{B}$ dengan menggunakan tujuh motor dan zona $\mathrm{B}$ dan $\mathrm{C}$ dengan menggunakan empat motor (Gambar 3). Patroli motor juga masuk ke area residensial/kluster perumahan meskipun sistem securitynya terpisah. Secara umum, zonasi A, B, C, D merupakan zonasi industrial estate yang meliputi $54 \%$ area dari total area Kota Deltamas. Sedangkan sisanya merupakan zona residensial dan komersil yang meliputi $46 \%$ dari total area Kota Deltamas. Yang menarik adalah terdapat kebutuhan spesifik dalam patroli yaitu kesenyapan kendaraan.
Menurut hasil wawancara, hal ini penting saat patroli masuk zona residensial atau saat akan melakukan penyergapan. Kebutuhan ini belum bisa dipenuhi oleh kendaraan patroli yang digunakan saat ini. Kendaraan listrik dapat menjadi opsi karena memiliki kelebihan, yaitu tidak bising (Kumara, 2008).

Penelusuran rute dan sampling jarak pos terjauh dan terdekat dilakukan untuk memperkirakan jarak patroli motor yang dalam sesi wawancara belum dapat dirata-ratakan oleh chief keamanan Kota Deltamas. Perkiraan jarak dari Damkar MS ke lampu merah MO Kota Deltamas kurang lebih 4,9 km. Maka apabila satu kali patroli melakukan satu kali putaran, maka jarak patroli kurang lebih adalah 9,8 km. Jarak ini relatif sama dengan kawasan residensial yang menjadi perhatian untuk penerapan E-Bike sebagai kendaraan operasional patroli keamanan. Jalur utama residensial sebagai batas luar yang mengelilingi area perumahan berjarak sekitar $5 \mathrm{~km}$. Jarak patroli akan bertambah bila patroli masuk ke dalam area perumahan. Jarak ini bisa diakomodasi oleh kendaraan listrik, karena kendaraan listrik untuk satu kali pengisian dapat menempuh lebih dari $20 \mathrm{~km}$ pada kondisi jalan mulus dan datar.

Hasil survey lapangan menunjukkan bahwa kondisi jalan beton beraspal hotmix serta terrain yang relatif datar sebetulnya tidak menuntut jenis motor trail

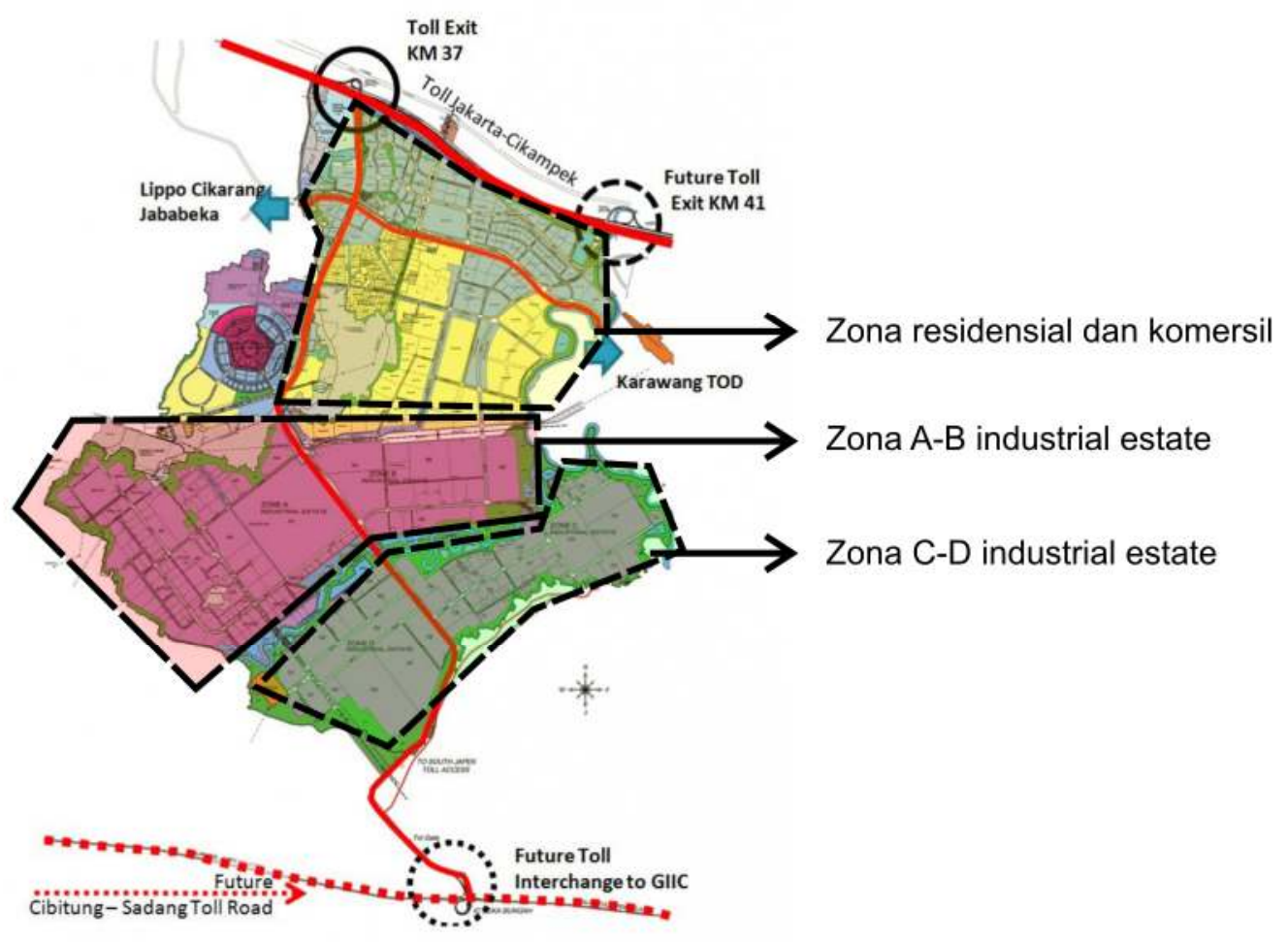

Gambar 3. Zonasi patroli keamanan Kota Deltamas 
seperti yang digunakan untuk berpatroli saat ini (Gambar 4 dan 5). Yang perlu diperhatikan adalah daya motor, akselerasi dan kecepatan E-Bike, karena dalam kondisi jalan seperti itu dalam kasus-kasus khusus, kecepatan dan akselerasi sangat diperlukan untuk melakukan pengejaran. Dalam hal ini secara khusus, chief keamanan Kota Deltamas menyarankan agar kendaraan dapat dipacu hingga $80 \mathrm{~km} / \mathrm{jam}$. Kebutuhan baru ini cukup signifikan untuk mengubah konfigurasi E-Bike secara keseluruhan karena sangat terkait dengan bentuk rangka, spesifikasi motor dan sistem kelistrikan yang akan digunakan.

\section{Pengembangan bentuk}

Pengukuran perceptual mapping dalam survey didapatkan 34 responden. Hasil perceptual mapping menunjukkan bahwa desain yang akan dikembangkan sebagai kendaraan patroli keamanan lebih mengarah ke offroad like - motorbike like sebagai harapan terhadap image produk (Gambar 6).

Studi sketsa bertujuan untuk mencari alternatif desain secara produktif. Studi sketsa difokuskan kepada pencarian bentuk. Hal ini dapat memancing temuan-temuan desain yang signifikan untuk dikembangkan/diterapkan. Studi sketsa menghasilkan 18 alternatif. Semua alternatif sudah diarahkan sesuai temuan perceptual mapping, yaitu offroad like motorbike like, di antaranya adalah dengan mengolah bentuk frame agar ground clearance tinggi, menghilangkan pedal, dan mengolah bentuk jok.

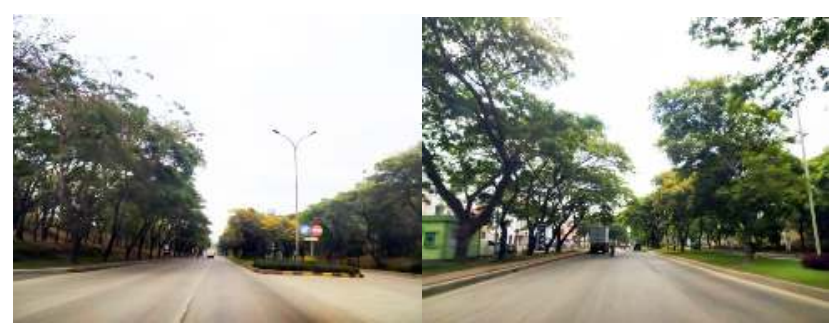

Gambar 4. Kondisi jalan dari lampu merah MO Kota Deltamas menuju GIIC/Damkar MS

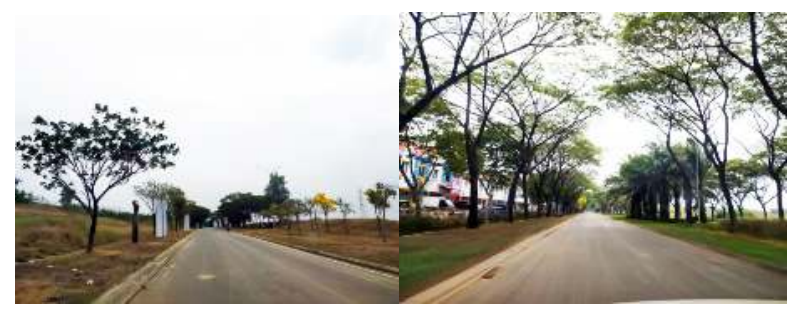

Gambar 5. Kondisi jalan dari kampus ITSB menuju lampu merah MO Kota Deltamas
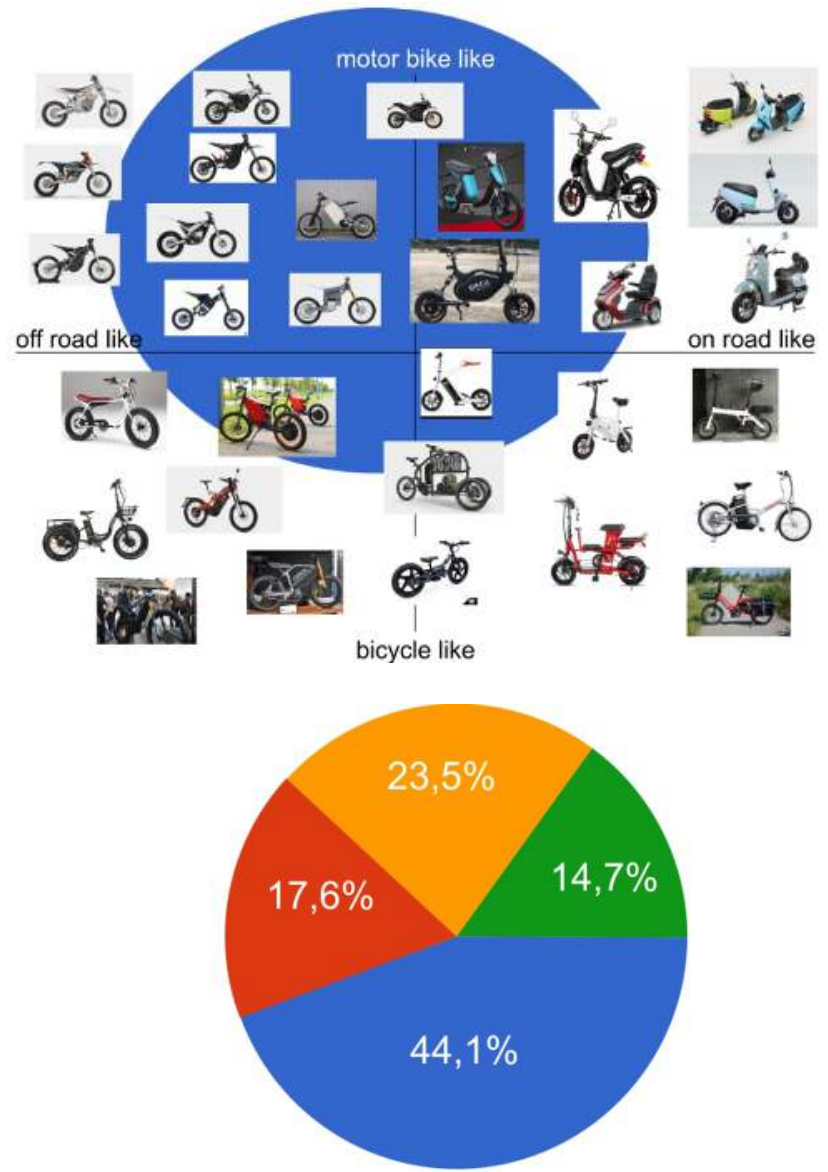

off road like - motor bike like (15 responden)

off road like - bicycle like ( 8 responden)

on road like - motor bike like (6 responden)

on road like - bicycle like (5 responden)

Gambar 6. Hasil perceptual mapping

Alternatif pada studi sketsa harus disaring kembali dengan diasosiasikan kepada temuan perceptual mapping. Hasilnya adalah dua alternatif desain EBike yang direkomendasikan untuk dikembangkan menjadi E-bike model 2.0. sesuai hasil perceptual mapping. Alternatif yang menjadi rekomendasi adalah alternatif nomor 16 dan nomor 3. Perceptual mapping menunjukkan bahwa image E-Bike ITSB model 2.0 untuk patroli yang diharapkan adalah offroadmotorbike like dengan persentase sebanyak $44,1 \%$. Dengan mengacu juga kepada kondisi jalan di Kota Deltamas, maka desain dapat berkesan offroad namun tidak perlu mengadaptasi model dirtbike. Hal ini juga selaras dengan $23,5 \%$ yang mengharapkan image on road like - motorbike like. Desain akan lebih bisa berhasil diterima bila lebih banyak mengakomodasi harapan responden. Dari ketiga alternatif terpilih sebagaimana tersebut di atas, alternatif 16 merupakan alternatif yang paling memenuhi kriteria tersebut (Gambar 7 dan 8). 

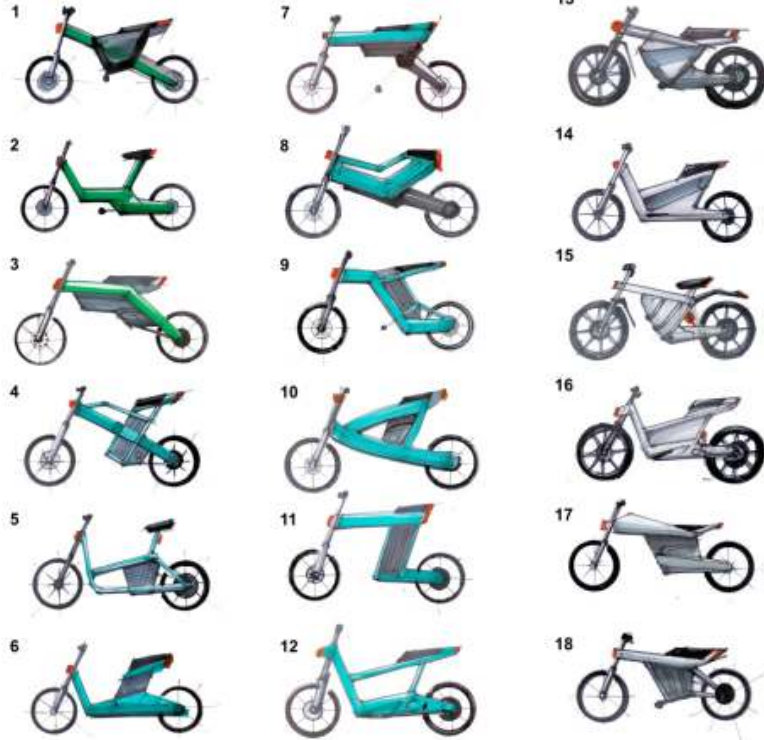

Gambar 7. Sketsa alternatif desain

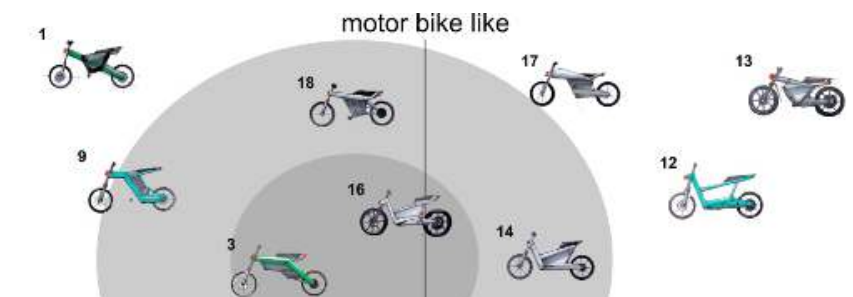

off road like
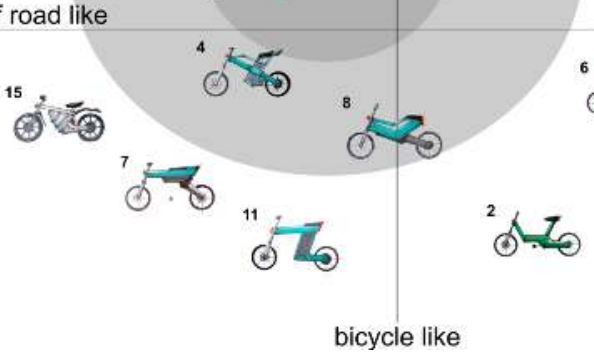

0

on road like

bicycle like

Gambar 8. Altenatif desain terpilih hasil pengasosiasian dengan hasil perceptual mapping

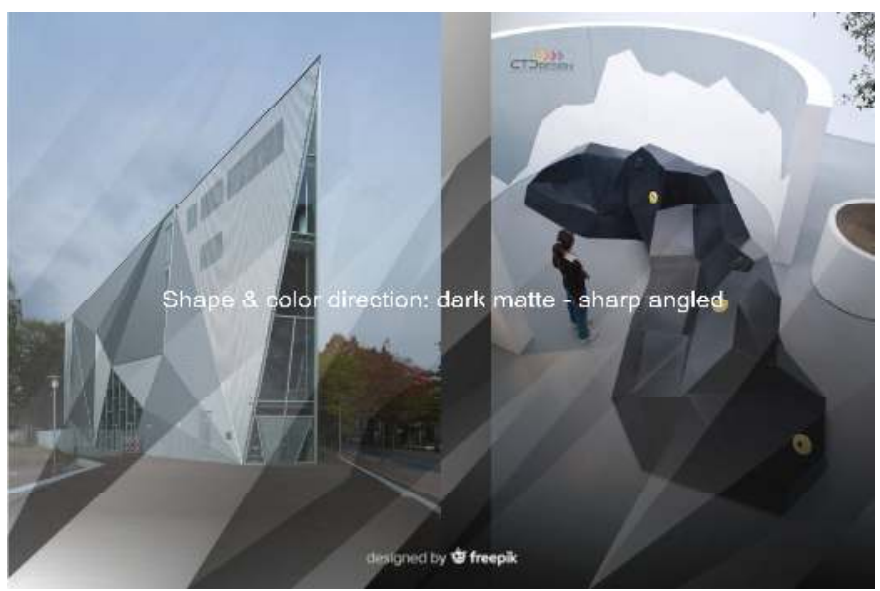

Gambar 9. Arah warna dan bidang yang diterapkan
Arah warna dan bidang ditetapkan melalui image board. Berbeda dengan perceptual mapping yang ditetapkan secara bottom up melalui survei responden, penetapan image dilakukan secara top down berdasarkan eksplorasi bentuk lurus bersudut. Bentuk seperti ini sekarang mulai banyak diterapkan, bahkan Cybertruck Tesla telah membuat arah desain dramatis dengan eksplorasi bentuk lurus bersudut. Kecenderungan ini dicoba diterapkan pada desain EBike ITSB 2.0. Adapun warna diputuskan berdasar pada image kendaraan patroli yang harus berkesan formal, outdoor dan kuat.

\section{Penetapan dimensi kasar produk}

Pengembangan desain terpilih dimulai dengan mempertimbangkan antropometri calon pengguna. Calon pengguna adalah satpam laki-laki dengan asumsi tinggi rata-rata $170 \mathrm{~cm}$ yang didasarkan pada data petugas keamanan di Kota Deltamas. Penetapan dimensi kasar produk diperoleh dengan metode analytical prototyping. Prosesnya diawali dengan program motorcycle ergonomic simulator. Dengan program ini, peneliti dapat memperoleh posisi pengendara pada berbagai tipe motor dengan ukuran manusia maupun kostumisasi motor yang berbedabeda. Program ini sebetulnya tidak cukup untuk pengukuran ergonomi yang akurat, namun sudah cukup untuk mendapatkan ilustrasi pengendara motor. Hasil ilustrasi dapat menentukan konfigurasi desain yang akan dikembangkan. Hasil simulasi lalu ditracing menggunakan program 3D smax untuk mendapatkan manekin manusia secara tiga dimensi yang gesturnya dapat disesuaikan dengan posisi berkendara sepeda motor.

Proses analytical prototyping diselesaikan di program 3D untuk mendapatkan bentuk dan ukuran utuh produk secara tiga dimensi. Di tahap ini, proses pengembangan desain terus dilakukan karena dengan cara tri dimensional konfigurasi bentuk dapat lebih terarah dan batasan-batasan awal teknis, seperti rake angle, ruang abdomen pengemudi, tinggi jok, posisi foot rest serta wheel base E-bike dapat diketahui. Di proses ini, manekin dapat lebih diilustrasikan untuk mendapatkan konfigurasi desain yang lebih baik. Desain rangka dan komponen utama E-Bike yang telah diperoleh melalui analytical prototyping ditetapkan sebagai dimensi kasar produk. Dalam tahap ini, maka ukuran-ukuran penting seperti whell base, lebar stang, ukuran roda, sudut kom stir dan rake angle, tinggi jok dan ukuran bounding box produk mulai ditetapkan.

Hasil temuan menunjukkan bahwa karakter desain E-Bike ITSB model 1.0. tidak dapat diterapkan 
Wildan Aulia, Heru Widodo

Pengembangan Desain E-Bike ITSB model 2.0. untuk kendaraan patroli keamanan kawasan terpadu

kepada desain E-Bike ITSB model 2.0. Beberapa hal yang muncul terkait kebutuhan penggunaan, seperti daya jelajah, akselerasi dan kecepatan, serta image produk telah mengubah konsep E-bike ITSB dan mengarahkan pengembangan desain kepada major change. Konfigurasi awal ditetapkan sebagai konsep dasar produk (Gambar 10). Dari konsep ini, pengembangan desain mulai diarahkan dengan mulai mempertimbangkan penggunaan komponen existing, yaitu motor, ban, dan velg. Terapan-terapan ini mengubah dan mengarahkan desain menjadi lebih baik karena telah dapat menampilkan gambaran utuh produk akhir.

Perubahan-perubahan bentuk maupun ukuran yang terjadi karena keterbatasan teknis, seperti komponen eksisting yang tidak cocok dengan konfigurasi awal dapat saja mengakibatkan perubahan desain, namun tidak boleh mengubah image produk (Gambar 11). Studi tersebut secara prematur dapat dilakukan dalam simulasi gambar maupun physical model dengan komponen lengkap yang mulai ditetapkan. Di tahap ini pula motor penggerak mulai harus ditetapkan. Sesuai kebutuhan yang teridentifikasi di sesi wawancara, bahwa E-bike ITSB harus bisa melaju hingga $80 \mathrm{~km} / \mathrm{jam}$, maka motor penggerak yang bisa direkomendasikan adalah motor dengan daya 3000 watt -7000 watt. Banyak pilihan tipe motor listrik yang sesuai, namun pada dasarnya harus bisa dipasangkan dengan baik mengacu ke dimensi rangka dengan penyesuaian-penyesuaian tertentu tanpa mengubah image produk. Tetapi dengan munculnya kebutuhan spesifik bahwa E-Bike tidak boleh bising, maka jenis motor yang paling cocok adalah motor jenis wheel-hub. Adapun motor jenis mid drive relatif lebih bising karena menggunakan rantai yang lebih mengeluarkan bunyi. Kelebihan lain wheel hub adalah kemudahan pemasangan serta struktur rangka bisa sederhana (Cheng, 2009).

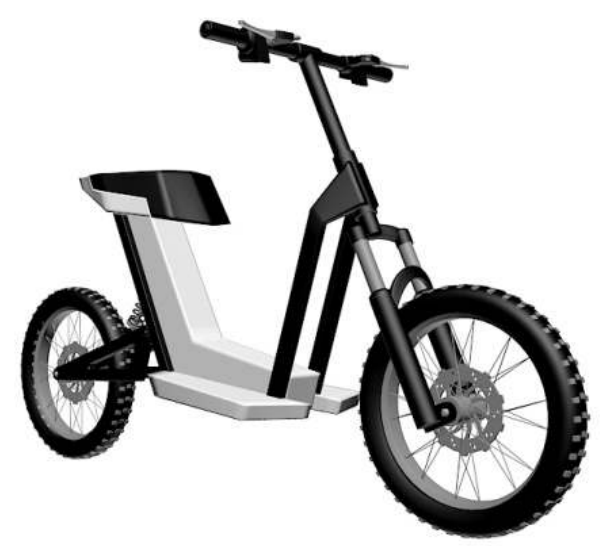

Gambar 10. Konfigurasi awal E-Bike ITSB model 2.0.
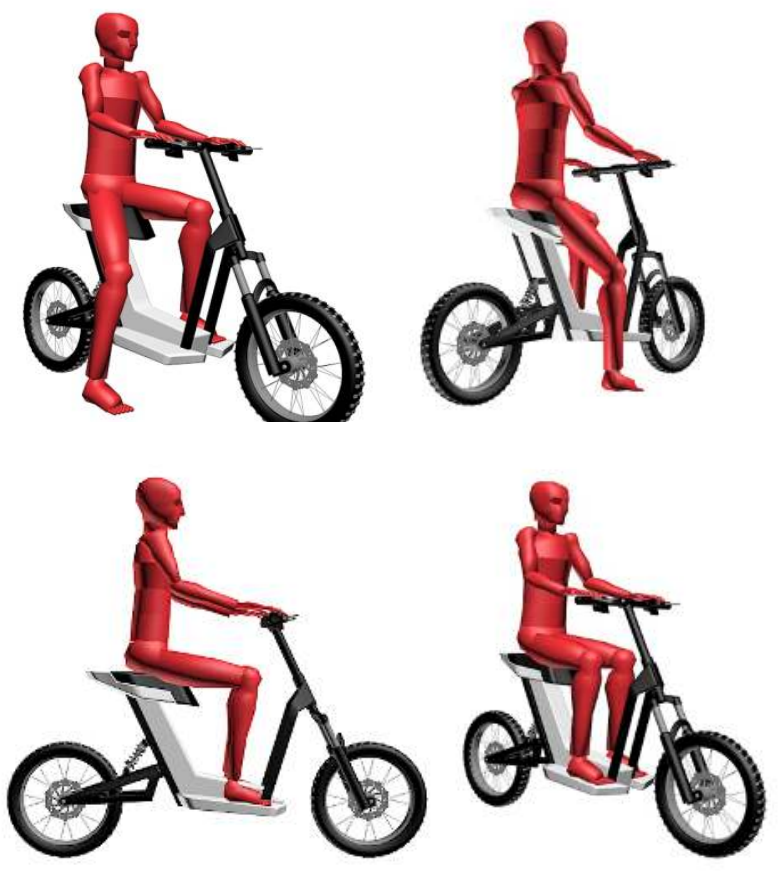

Gambar 11. Ilustrasi pengendara E-Bike ITSB model 2.0. dengan manekin laki laki tinggi $173 \mathrm{~cm}$.
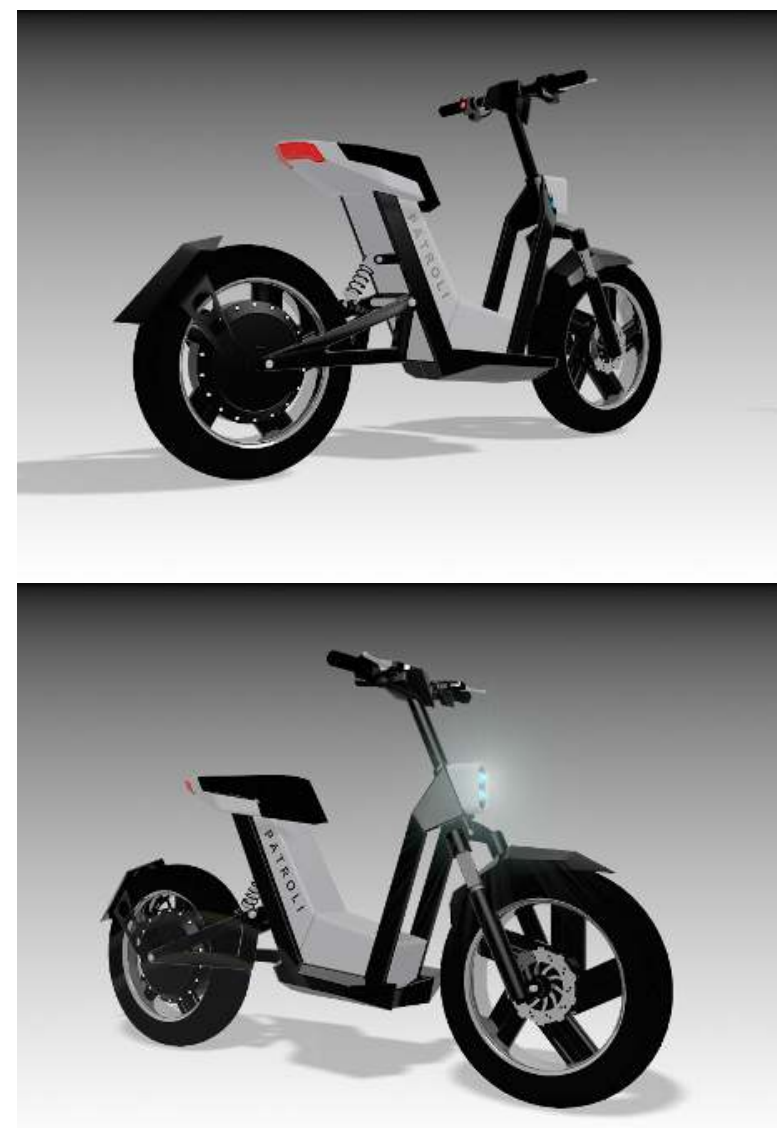

Gambar 12. Contoh desain E-Bike ITSB model 2.0. dengan motor hub QS 5000W 17 inch dan ukuran ban 120/70-17. 


\section{Penutup}

Pengembangan desain E-Bike ITSB 2.0. berangkat dari kebutuhan penggunaan meliputi jarak tempuh, tipe terrain, faktor kesenyapan, yang kemudian menuju bentuk, image dan konfigurasi berdasar pada antropometri pengguna dan harapan publik terhadap image E-Bike ITSB 2.0. Penetapan komponen motor diarahkan oleh kebutuhan tersebut. Oleh karenanya, bila desain ini akan dikembangkan lebih jauh maka penulis menyarankan untuk melakukan studi dan pengujian pada:

1. Aspek engineering struktur rangka berkaitan dengan tipe chassis, titik beban dan gravitasi, dan sistem suspensi selain material rangka. Semuanya harus mempertimbangkan kekuatan, bobot, dan nilai kelenturan (Purnomo et al, 2017).

2. Aspek kelistrikan meliputi sumber energi, daya listrik, penyimpanan energi (Ding et al, 2017); kontroler dan instalasi yang diarahkan kepada sistem operasi optimum, meliputi starting, akselerasi, daya jelajah, pengereman, power regeneration dan berhenti (Kumara, 2008; Cheng, 2009).

3. Aspek skema penggunaan dan infrastruktur pendukung. Hal ini penting karena jenis battery electric vehicle memerlukan waktu lama untuk pengisian daya batere (Ding et al, 2017). Kebutuhan terhadap waktu pengisian batere dapat mengubah pola patroli yang sudah berjalan.

Tiga aspek pengembangan tersebut harus dilakukan secara multidisiplin agar pengembangan dapat terukur dengan baik. Langkah lanjutannya adalah comprehensive prototyping, yaitu membangun rancangan yang sudah dapat dikendarai untuk proses pengujian, namun belum sampai tahap simulasi produksi dan penetapan komponen standar. Di tahap comprehensive prototyping ini, maka HAKI Desain Industri disarankan diajukan dengan klaim pada bentuk, konfigurasi dan warna.

Di luar itu, skema penggunaan E-Bike ITSB juga harus ditawarkan sebagai antisipasi dari keterbatasan penggunaan kendaraan karena faktor pengisian daya batere maupun jarak maksimum batere dalam sekali pengisian. Sistem solar sel seperti yang diterapkan pada model E-Bike 1.0. bisa saja diterapkan kembali namun untuk pengisian batere cadangan, bukan pengisian utama. Solar panel harus menggunakan solar panel tipe semi flexi dengan ukuran modul kecil yang dapat ditempelkan pada bodi E-Bike ITSB 2.0. tanpa mengganggu konfigurasi desain. Hal ini sebagai upaya memperpanjang waktu penggunaan E-Bike. Selain itu, shelter pengisian batere bisa juga dijadikan penelitian lanjutan yang diarahkan untuk sinkron dengan pos-pos peristirahatan petugas patroli sesuai hasil survey dalam penelitian ini.

Akhir kata penulis mengucapkan terima kasih kepada Direktorat Riset dan Pengabdian Masyarakat RISTEKDIKTI Republik Indonesia atas program Pendanaan Penelitian Perguruan Tinggi Non-PTNBH Tahun Anggaran 2020 sehingga penelitian ini dapat diselesaikan.

\section{Daftar pustaka}

Aulia,W. \& Widodo, H. (2018). Perencanaan Shelter Sepeda Listrik Bertenaga Surya untuk Diterapkan Di Kawasan Green Office Park, BSD City, Tangerang. Planners InSight, volume 1, no. 2, November 2018, hal. 10 - 21, ISSN 2615-7055.

Cheng, K. W. E. (2009). Recent Development on Electric Vehicles. 3rd International Conference on Power Electronics Systems and Application.

Ding, N. et al. (2017) The Electric Vehicle: a Review. International Journal of Electric and Hybrid Vehicles, January Vol. 9, No. 1, 2017. hal. $49-65$.

Handoyo, O \& Lutfiah, G. (2016). Desain Kendaraan Roda Dua Bertenaga Matahari. Proceedings SENIATI 2016, Green Technology Innovation, 6 Februari 2016, hal. D.25-1 - D.25-6, ISSN: 2085-4218. Malang: Fakultas Teknologi Industri Institut Teknologi Nasional Malang.

https://deltamas.id/masterplan/ Diakses tanggal 2 September 2020

Kumara, S. N. (2008). Tinjauan Perkembangan Kendaraan Listrik Dunia Hingga Sekarang. Transmisi, Jurnal Teknik Elektro, Jilid 10, Nomor 2, Juni 2008, hal. 89 - 96, p-ISSN: 1411-0814; e-ISSN: 2407-6422.

Milton, A., Rodgers, P. (2013). Research Methods for Product Design. London: Laurence King Publishing.

Purnomo, S. J. et al. (2017). Uji eksperimental Kinerja Mobil Listrik. Prosiding SNATIF Ke -4 Tahun 2017, Fakultas Teknik - Universitas Muria Kudus, hal. 679 - 686. ISBN: 978-6021180-50-1.

Romli. (2018). Perancangan Mobil Listrik sebagai Alat Transportasi Umum untuk Kawasan Kota Deltamas. Tugas Akhir. Bekasi: Institut Teknologi Sains Bandung. 